\title{
The Analysis of Enterprise Risk Management and Earnings Volatility: Moderation of Audit Committee and Audit Quality
}

\author{
Endah Ningtyas ${ }^{1}$ and Desi Adhariani ${ }^{2}$ \\ Faculty of Economics and Business, Universitas Indonesia, Indonesia ${ }^{1,2}$ \\ 12endahtyastomo@gmail.com, 22desi.adhariani@ui.ac.id
}

\begin{abstract}
This study aims to analyze the impact of enterprise risk management (ERM) implementation on earnings volatility with audit committee effectiveness and audit quality as the moderating variables. The effectiveness of ERM implementation is assessed using a disclosure index developed based on guidance issued by COSO. Earnings volatility is measured using the standard deviation of the firm's net income before extraordinary items, divided by total assets of the company. The effectiveness of the audit committee was assessed using a checklist of audit committee effectiveness criteria, and the auditquality was measured by dummy variables (Big Four and non-Big Four). Data from a sample of companies listed on the Indonesia Stock Exchange was collected for the period 2012-2016. The results of this study indicate that the effectiveness of ERM implementation has a negative associationwith earnings volatility. The effectiveness of the audit committee is found to strengthen the association between the effectiveness of ERM implementation and earnings volatility, but audit quality was found not havinga moderating effect. This research has a practical implication on improving the role of audit quality to complement the oversight function delivered by the audit committee.
\end{abstract}

Keywords: $\quad$ Enterprise Risk Management; Earnings Volatility; Audit Committee Effectiveness; Audit Quality

\section{Introduction}

Global economic conditions that continue to grow and cause complexity in the business world requires business people to know the various exposure of risks faced by their companies. Supervision and handling of risk exposure to business processes are one of the most basic requirements for the implementation of the risk management process [1]. Lack of monitoring and handling of risk exposure can have a negative impact on acompany, one of which is demonstrated by the achievement of unstable earnings. Earnings volatility can affect the accuracy of earnings prediction for users of financial statements. Edmonds et al. [2] explain the higher level of earnings volatility indicates the higher the possibility of companies experiencing financial 
problems or financial distress. Akbari et al. [3] and Edmonds et al. [4]in his research explains that the proper handling and response to risk exposure through effective enterprise risk management (ERM) implementation can reduce the direct and indirect costs associated with the financial distress experienced by a company.

Implementation of ERM cannotbe separatedfrom the governance of an organization. A form of implementation of corporate governance principles according to Organization for Economic Cooperation and Development [5] especially the 5th principle and the 6th principle can be reflected through the implementation of ERM in the company [6]In addition to risk reporting, the implementation of OECD's fifth principles of corporate governance on disclosure and transparency can also be realized through audit quality in the financial statements and the role of external auditors. Andarini and Fithri [7]researched the influence of external auditors' reputation on the existence of risk management functions. Inconsistent with the hypothesis, the results prove that the auditor's reputation is not significantly related to the effectiveness of corporate risk management functions. In addition to the implementation of OECD's fifth corporate governance principles, ERM implementation is also a form of implementation of the OECD's sixth corporate governance principles on the responsibilities and roles of councils and directors. Not only the role of directors through the implementation of ERM, the responsibilities and roles of committee councils are also required in implementing thisprinciple, for example, the role of the audit committee within the company. Main research conducted in 2004 states that the audit committee can assist the board of commissioners in overseeing the company's financial performance and activities and ensuring riskrelated and risk-control recommendations are implemented.

Previous research by Edmonds et al[8]providesempirical evidence that a company can significantly achieve lower earnings volatility by improving the quality of ERM implementation. However, different results were obtained by Akbari et al. [3]found that the level of risk management effectiveness simultaneously did not affect earnings volatility. In addition, there are studies conducted by Chandra [9] to examine the possibility of a positive relationship between the effectiveness of audit committees on the relevance and predictability of earnings, but the results show that the effectiveness of audit committees does not provide additional relevance and an increase in the level of earnings predictability. From the review of the findings and results of previous research related to the effectiveness of ERM implementation, corporate governance mechanisms in terms of the audit committee and audit quality, and the measurement of earnings volatility, this research is conducted to test and analyze more deeply the effect of ERM implementation effectiveness on earnings volatility. This research is motivated by the mixed results in the previous studies. This study investigated the role of the audit committee's effectiveness and audit quality in influencing the relationship between ERM implementation and earnings volatility, which has not much studied in previous research. Previous studies conducted by Akbari et al. [10] and Edmonds et al. [11]does not include internal oversight factors from audit committees and external oversight factors from independent auditors in measuring the effect of ERM on earnings volatility.

Based on the above background, the research questions to be answered in this study are as follows:

1. Is there a negative association between the effectiveness of ERM implementation and earnings volatility?

2. Will the higher audit committees' effectiveness strengthen the negative association between the effectiveness of ERM implementation and earnings volatility?

3. Will higher audit quality strengthen the negative association between the effectiveness of ERM implementation and earnings volatility? 
4. Will the higher audit committees' effectiveness and higher audit quality simultaneously strengthen the negative association between the effectiveness of ERM implementation and earnings volatility?

\section{Theoretical Review}

\section{a. Stewardship Theory}

Davis and Donaldson [7] explain that the stewardship theory explains the executive or management behavior as the stewards of thecompany.Based on this theory, the executive or management will be motivated to act as best as possible to maximize the interest of the principal. Stewards will endeavor to protect and maximize the welfare of stake holder sthrough good corporate performance so thatthe management function of the companyis considered to be optimal from the eye of stakeholders .Daniri [7]states philosophical assumptions that describes tewardship theoryas an effective theory to explaingood corporate governancepracticesin the company, such as ERM implementation, audit committee role in supervising company, and examination of company financial report conducted by an independentauditor.It can also be concluded that thes tewardship theoryis one of the effective theories to explain the implementation of ERM in the company.The effective implementation of ERM within the company will assist the managers of the company or management in achieving the company's objectives, including the fulfillment of profit targets.Achieving profits that match their targets for each period indicates low levels ofearnings volatility andg ood corporate performance.

The implication of stewardship theory in this research is to explain the evidence of management responsibility as the manager of the company in fulfilling and protect thestakeholder'sinterest,especially the shareholders asprincipal, through the effective implementation of ERM to achieve persistentearningslevel and low earnings volatility.Stewardshiptheorycan also be used as a basis to explain the role of audit committees in conducting oversight of the company. The composition of an independent audit committee members, committee activities, as well as the competence of the audit committee, willcorrelatewith the financial performance [12]Similarly, for external audit activities, stewardship theory is also able to explain the role of independent auditors in examining the company's financial statements. The independent auditor may provide guidance on appropriate good corporate governance practices to be applied, assisting internal auditors in evaluating and improving the effectiveness of risk management thereby enhancing the quality of risk assessment and monitoring of the company [12]

\section{b. Development of Hypotheses}

Achieving good financial performance and steadily increasing profit levels is one of the company's key objectives. Good financial performance can be demonstrated through high levels of earnings persistence, or low earnings volatility. Low earnings volatility isalso one of the main objectives of ERM implementation. This objective is related to the company's ability to reduce direct and indirect costs incurred to handle financial distress risks. Akbari et al. [3]found that the level of risk management effectiveness has no impact on earnings volatility. However, different results were obtained by Edmonds et al. 's [8]who found that changes in the quality of ERM implementation are strongly associated with changes in earnings volatility levels. Based on these reviews, the hypothesis developed in this study are as follows:

H1: There is a negative relationship between the effectiveness of ERM implementation with earnings volatility.

In performing its duties, members of the audit committee shall act independently and not attempt to represent the interests of one party in the enterprise. Previous research by Chandra [10] 
proves that the effectiveness of the audit committee does not provide additional relevance and predictability of the net profit value of operating activities. Another research conducted by Syifa states that the audit committee can assistthe board of commissioners in overseeing the company's financial performance and activities and ensuring risk-related and risk-control recommendations are implemented.Previous studies on the audit committee effectiveness can illustrate the increasing effectiveness of audit committees will strengthen the negative relationship between the effectiveness of ERM implementation and earnings volatility. Based on this, we developed the following hypotheses:

$\mathrm{H} 2$ : Higher audit committee effectiveness reinforces the negative effect of ERM implementation effectiveness on earnings volatility.

[8][13]As part of the monitoring function, a qualified external auditor will assist the oversight tasks performed by the audit committee, whether overseeing the company's financial activity, or control over the company's risk management. Companies or reputable public accounting firms can produce good audit quality, in accordance with the results of research conducted by Becker, DeFond, and California [13]DeAngelo [9]Van Caneghem [9]Watts and Zimmerman[7] found that top auditing firms such as the Big Four can provide higher audit quality than non-Big Four auditing firms. Andarini and Januarti [14]researched the influence of external auditors' reputation on the existence of risk management functions within the company. But unlike the hypothesis developed, the results of his research prove that the auditor's reputation is not significantly related to the effectiveness of corporate risk management functions. Another study conducted by Mutmainah states that companies using big Four KAP have a positive effect on the persistence and predictability of earnings level. High-quality audits will strengthen the control and monitoring functions in managing corporate risk.The negative relationship between the effectiveness of ERM implementation and the earnings volatility of a company can be reinforced by high audit quality, which is proxied through KAP measures. Therefore, the formulation of hypotheses that can be developed is:

H3: Higher audit quality strengthens the negative effect of ERM implementation effectiveness on earnings volatility.

In accordance with the development of previous hypotheses regarding the effectiveness of the audit committee and audit quality in strengthening the negative relationship between ERM implementation and the level of earnings volatility, the effectiveness of the audit committee and audit quality simultaneously and simultaneously are expected to encourage the effectiveness of ERM implementation within the company. The effectiveness of audit committees proxied by the independence, size, activity, and competence of committee members; and the quality of audits proxied by the reputation or size of KAP, simultaneously is expected to also support improvements in the financial performance of the company, so that the profits derived by the company increase steadily from year to year. Related to this, the development of the proposed hypothesis is as follows:

H4: The effectiveness of audit committees and higher quality audits simultaneously can strengthen the negative impact of ERM implementation effectiveness on earnings volatility

\section{Research Methods}

a. Regression Model

Some regression models used in this study can be described as follows: 
Model 1: Regression model used to test hypothesis 1, i.e.,the effectiveness of ERM implementation has a negative effect on earnings volatility:

$\mathrm{EV}_{\text {it }}=\beta_{0}+\beta_{1} \mathrm{ERM}_{\text {it }}+\beta_{2} \mathrm{LeV}_{\text {it }}+\beta_{3} \mathrm{PBV}_{\text {it }}+\beta_{4}$ Size $_{i t}+\beta_{5}$ ROA $_{\text {it }}+\beta_{6}$ PER $_{\text {it }}$

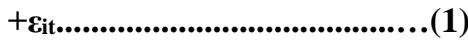

Information:

\begin{tabular}{|l|l|}
\hline EV & Earnings volatility (profit volatility) \\
\hline ERM & The effectiveness of ERM implementation \\
\hline Lev & Leverage ratio \\
\hline PBV & Price to book value ratio \\
\hline Size & Company size \\
\hline ROA & Return on asset \\
\hline PER & Price-earnings ratio \\
\hline E & $\begin{array}{l}\text { Error, i.e., the possibility of other variables affecting profit volatility but not } \\
\text { considered in the study }\end{array}$ \\
\hline
\end{tabular}

Model 2: The regression model used to test hypothesis 2, i.e., the negative relationship between the effectiveness of ERM implementation and earnings volatility can be moderated by the effectiveness of the audit committee:

$\mathrm{EV}_{\mathrm{it}}=\beta_{0}+\beta_{7} \mathrm{ERM}_{\mathrm{it}}+\beta_{8} \mathrm{ACE}_{\mathrm{it}}+\beta_{9} \mathrm{ERM}_{\mathrm{it}} * \mathrm{ACE}_{\mathrm{it}}+\beta_{10} \mathrm{LeV}_{\mathrm{it}}+\beta_{11} \mathrm{PBV}_{\mathrm{it}}+\beta_{12} \mathrm{Size}_{\mathrm{it}}+\beta_{13} \mathrm{ROA}_{\mathrm{it}}$

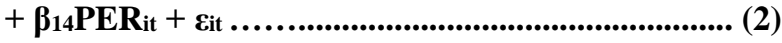

Information:

\begin{tabular}{|l|l|}
\hline ACE & $\begin{array}{l}\text { Audit Committee } \\
\text { effectiveness(effectiveness of the } \\
\text { audit committee) }\end{array}$ \\
\hline ERM * ACE & $\begin{array}{l}\text { Interaction variable effectiveness } \\
\text { of ERM implementation with } \\
\text { effectiveness variable audit } \\
\text { committee }\end{array}$ \\
\hline
\end{tabular}

Model 3: Regression model used to test hypothesis 3, i.e., the negative relationship between the effectiveness of ERM implementation and earnings volatility can be moderated with audit quality: $\mathrm{EV}_{\text {it }}+=\beta_{0}+\beta_{15} \mathrm{ERM}_{\mathrm{it}}+\beta_{16} \mathrm{AQ}_{\mathrm{it}}+\beta_{17} \mathrm{ERM}_{\mathrm{it}} * \mathrm{AQ}_{\mathrm{it}}+\beta_{18 L e v i t}+\beta_{19} \mathrm{PBV}_{\mathrm{it}}+\beta_{20} \mathrm{Size}_{i t}+$ $\beta_{21} R_{1} O A_{i t}+\beta_{22} P{ }_{1} R_{i t}+\varepsilon_{i t}$ (3)

Information:

\begin{tabular}{|l|l|}
\hline AQ & \multicolumn{3}{|l|}{ Audit Quality (audit quality) } \\
\hline ERM * AQ & $\begin{array}{l}\text { Interaction variable of the } \\
\text { effectiveness } \\
\text { implementation of with audit } \\
\text { quality variable }\end{array}$ \\
\hline
\end{tabular}

Model 4: The regression model used to test hypothesis 4, i.e., the negative relationship between the effectiveness of ERM implementation and earnings volatility can be moderated by the effectiveness of the audit committee and audit qualities:

$\mathrm{EV}_{\text {it }}=\beta_{0}+\beta_{23} \mathrm{ERM}_{\mathrm{it}}+\beta_{24} \mathrm{ACE}_{\mathrm{it}}+\beta_{25} \mathrm{AQ}_{\mathrm{it}}+\beta_{26} \mathrm{ERM}_{\mathrm{it}} * \mathrm{ACE}_{\text {it }}+\mathrm{B}_{27} \mathrm{ERM}_{\mathrm{it}} * \mathrm{AQ}_{\mathrm{it}}+$ $\beta_{28} L_{e V}+B_{29}$PBV $_{\text {it }}+\beta_{30}$Size $_{i t}+\beta_{31}$ROA $_{\text {it }}+\beta_{32}$PER $_{\text {it }}+\varepsilon_{\text {it }}$ 


\section{b. Sample Selection}

The sample used for testing in this research is manufacturing companies listed on the BEI from 2012 until 2016. From 2012 to 2016, the total number of companies tested is the same in each year, which is 116 companies. From the initial data of 144 companies listed on the IDX during the period 2012-2016, there are 28 data companies with the availability of incomplete data, so issued as a sample. Details of the selected sample selection can be described as follows:

Table 1: Selection of Research Sample

\begin{tabular}{|l|l|}
\hline Description & Amount \\
\hline Manufacturing companies listed on the Stock Exchange 2012-2016 & 144 \\
\hline Manufacturing companies with incomplete data & $(28)$ \\
\hline Manufacturing companies used as samples & 116 \\
\hline Research period (2012-2016) & 5 \\
\hline Total observations (116 companies x 5 years) & $\mathbf{5 8 0}$ \\
\hline
\end{tabular}

\section{c. Classic Assumption Test and Test of Statistical Criteria}

The test of econometric criteria with the classical assumption is done in this research so that the research model used is avoided from the problems that can make the research inaccurate and inefficient. The data used in the study should be ensured free of violation of classical assumptions. Three problems that often cause the research model is not best, linear, unbiased, and efficient (BLUE) is multicollinearity, heteroscedasticity, and autocorrelation. Furthermore, to test the research hypothesis used some statistical criterion that is a significant test model (F-Test), partial test (t-Test) and goodness of fit test.

\section{Results And Discussion}

\section{a. Descriptive Statistics}

The description of descriptive statistic serves to give a general description of each variable tested. From the descriptive statistics, the table presented the average value, standard deviation, minimum value, and the maximum value of each variable. The main variables used in this research are EV and ERM. Descriptive statistical results of EV variables showed an average value of 0.048 , the minimum value of -1.279 , and a maximum value of 0.657 . This means that the average volatility level of manufacturing companies in Indonesia in 2012-2016 amounted to 4.8\%, and the highest profit volatility level was $6.57 \%$. The minimum value at $\mathrm{EV}$ is negative $-1,279$ means that during that period there is a manufacturing company that suffers losses. EV standard deviation value greater than its mean value indicates that EV data varies widely or spreads. Furthermore, for the variable average value, ERM produced was 9.328, the value of a standard deviation of 1.347, a minimum value of 6 and a maximum value of 11. Theaverage use values N ERM shows scores that exceed the value of the middle scores ERM $(9.328>8)$ indicates that most manufacturing companies in Indonesia have implemented ERM quite well in accordance with most of the COSO set criteria.

The first moderation variable used in this study was ACE, i.e., the effectiveness level of the audit committee. The ACE value in the descriptive statistics tableshows an average value of 27.4, a standard deviation value of 0.018 , a minimum value of 23 , and a maximum value of 30 . In the table it can be seen that the average ACE value obtained exceeds the middle score of the ACE score (27.4> 22), which indicates that most manufacturing firms in Indonesia have an audit 
committee function that is quite effective in accordance with most of the audit committee effectiveness criteria developed by Hermawan (2009). The second moderating variable used in this study is audit quality measured using dummy size KAP. From the descriptive statistics,it can be seen that the minimum value of AUD is 0 and its maximum value is 1 indicating the dummy value of audit quality variable, i.e.,one if audited by KAP Big Four and 0 if audited by KAP other than Big Four. From the table it can be seen if the average for AUD is 0.397 or equal to $39.7 \%$, this result shows that from a sample of manufacturing company used in research $39,7 \%$ sample is audited by Big Four KAP and the rest equal to $60,3 \%$ audited by nonBigFour. Descriptive statistical results for four research models used each described as follows:

Table 2: Descriptive Statistics Testing Model 1 - Model 4

\begin{tabular}{|c|c|c|c|c|c|}
\hline Variable & $\begin{array}{l}\text { Observatio } \\
\text { n }\end{array}$ & Average & $\begin{array}{l}\text { Standard } \\
\text { Deviation }\end{array}$ & Min. & Max. \\
\hline $\mathrm{EV}$ & 580 & 0,048 & 0,116 & $-1,279$ & 0,657 \\
\hline ERM & 580 & 9,238 & 1,347 & 6,000 & 11,000 \\
\hline $\mathrm{ACE}$ & 580 & 0,274 & 0,018 & 0,230 & 0,300 \\
\hline $\mathrm{AQ}$ & 580 & 0,397 & 0,486 & 0,000 & 1,000 \\
\hline $\begin{array}{l}\text { ERMAC } \\
\text { E }\end{array}$ & 580 & 2,813 & 0,271 & 1,320 & 3,300 \\
\hline ERMAQ & 580 & 3,538 & 4,454 & 0,000 & 11,000 \\
\hline LEV & 580 & 0,469 & 0,278 & 0,000 & 0,988 \\
\hline PBV & 580 & 2,781 & 7,431 & 0,002 & 80,845 \\
\hline $\begin{array}{l}\text { SIZE } \\
(\mathrm{Rp} 000)\end{array}$ & 580 & $\begin{array}{l}8.712 .876 .62 \\
4\end{array}$ & 24.837 .249 .123 & $\begin{array}{l}92.041 .27 \\
4\end{array}$ & $\begin{array}{l}261.855 .000 .00 \\
0\end{array}$ \\
\hline LNSIZE & 580 & 0,489 & 1,310 & $-3,097$ & 3,311 \\
\hline ROA & 580 & 0,051 & 0,122 & $-1,279$ & 0,657 \\
\hline PER & 580 & 0,006 & 0,482 & $-7,284$ & 2,880 \\
\hline \multicolumn{6}{|c|}{ Dummy Variable } \\
\hline & & \multicolumn{2}{|l|}{$\% 1$} & \multicolumn{2}{|l|}{$\% 0$} \\
\hline $\mathrm{AQ}$ & & \multicolumn{2}{|l|}{$39,65 \%$} & \multicolumn{2}{|l|}{$60,35 \%$} \\
\hline \multicolumn{6}{|c|}{ Description } \\
\hline EV & \multicolumn{5}{|c|}{ Earnings volatility } \\
\hline ERM & \multicolumn{5}{|c|}{ ERM effectiveness } \\
\hline $\mathrm{ACE}$ & \multicolumn{5}{|c|}{ Audit Committee Effectiveness } \\
\hline $\mathrm{AQ}$ & \multicolumn{5}{|c|}{ Audit Quality } \\
\hline ERMACE & \multicolumn{5}{|c|}{ The interaction between ERM and ACE } \\
\hline ERMAQ & \multicolumn{5}{|c|}{ The interaction between ERM and ACQ } \\
\hline LEV & \multicolumn{5}{|c|}{ Leverage ratio } \\
\hline PBV & \multicolumn{5}{|c|}{ Price to book value ratio } \\
\hline SIZE & \multicolumn{5}{|c|}{ Company size } \\
\hline LNSIZE & \multicolumn{5}{|c|}{ Natural logarithm of total assets } \\
\hline ROA & \multicolumn{5}{|c|}{ Return on asset } \\
\hline PER & \multicolumn{5}{|c|}{ Price-earnings ratio } \\
\hline
\end{tabular}

\section{b. Hypothesis Testing Results}

Test results from each hypothesis/model can be summarized and explained as follows: 
Table 3. Table Results of Regression Testing Model 1

Regression Model Results 1

Hypothesis1: The effectiveness of ERM implementation has a negative effect on earnings volatility

Model 1: EVit $=\beta 0+\beta 1(\mathrm{ERM})$ it $+\beta 2(\mathrm{Lev})$ it $+\beta 3(\mathrm{PBV})$ it $+\beta 4$ (Size) it $+\beta 5$ (ROA) it $+\beta 6$ (PER) it + cit

\begin{tabular}{|l|l|l|l|l|}
\hline Variables & Results Expectations & Coefficient & p-value & Significance \\
\hline ERM & - & $-0,559$ & 0.003 & $* * *$ \\
\hline LEV & + & 0.205 & 0.014 & $* *$ \\
\hline PBV & - & -0.296 & 0.063 & $* *$ \\
\hline SIZE & - & $-0,865$ & 0.013 & $* *$ \\
\hline ROA & - & $-0,032$ & 0.065 & $*$ \\
\hline PER & - & -1.277 & 0.039 & $* *$ \\
\hline Cons & & -0.206 & 0.022 & \\
\hline R Squared & $19,554 \%$ & & & \\
\hline Adj R Squared & $18.402 \%$ & & & \\
\hline Prob> F & 0.002 & & & \\
\hline
\end{tabular}

$* * *$ Significance at level $1 \%$ (one-tailed)

** Significance at level $5 \%$ (one-tailed)

* Significance at level $10 \%$ (one-tailed)

\section{Information:}

$\mathrm{EV}=$ earnings volatility, is the standard deviation of profit; ERM = Enterprise Risk Management, is the effectiveness of ERM implementation score; LEV = leverage ratio, proxied by the ratio of total debt per total asset; $\mathrm{PBV}=$ price to book value ratio; SIZE = firm size proxies with the natural logarithm of total assets; ROA = return on asset ratio; PER $=$ price earnings ratio

The result of regression test of model 1 shows that the independent variables used are ERM, LEV, PBV, SIZE, ROA, and PER have the ability of $18.402 \%$ to explain the dependent variable is EV. While the rest of $81,598 \%$ is explained by other factors outside the independent variable used in research, the value of the p-value generated from the regression performed is 0.003 which indicates the ERM variable has a significant effect on the level of $1 \%$ to the EV. The resulting direction for the relationship between ERM and EV is negative as expected. The results obtained from this test indicate that the effective implementation of ERM by the company has a negative effect on earnings volatility of the company. The results of this study are consistent with the results of research proposed by Edmonds et al. [2] who find that changes in the quality of ERM implementation have a strong negative relationship with changes in earnings volatility levels. From the translation for the results of the regression hypothesis 1 above, it can be concluded if hypothesis 1 in this research is accepted.

Furthermore, the results of testing the 2 nd hypothesis can be seen in table 4 . Based on the regression result of adjusted $\mathrm{R}^{2}$ is produced is $19.017 \%$. The result shows that independent variable that is used is ERM, moderate variables are ACE and ERMACE, and control variables are LEV, PBV, SIZE, ROA, and PER have ability equal to $19,017 \%$ to explain dependent variable $\mathrm{EV}$. The result of regression model 2 for ERM and EV relationship gives almost the same result with the regression result that resulted from model 1 which has been described previously. In model 2, the test is emphasized to see if the high effectiveness of audit committees in 
manufacturing companies will be able to weaken the negative relationship or moderate the relationship between ERM implementation and earnings volatility. When the ERM and EV variables are moderated with the effectiveness of the ERMACE audit committee, it can show stronger strong results with a p-value value of 0.048 lower than $\alpha 5 \%$ and $10 \%$. The value can be seen in table 4 for ERMACE which is the interaction between ERM and ACE. The resulting direction is negative with a coefficient of -0.846 , and the resulting direction in accordance with the expected. With these results, it can be concluded that the effectiveness of the audit committee is able to moderate the relationship between ERM implementation and earnings volatility.

Table 4: Results of Regression Testing Model 2

\begin{tabular}{|c|c|c|c|c|}
\hline \multicolumn{5}{|c|}{ Regression Result Model 2} \\
\hline \multirow{2}{*}{\multicolumn{5}{|c|}{$\begin{array}{l}\text { Hypothesis 2: The negative relationship between the effective } \\
\text { and earningsvolatility can be moderated by the effectiveness of the audit co } \\
\text { Model 2: } E V i t=\beta 0+\beta 7(\mathrm{ERM}) \text { it }+\beta 8(\mathrm{ACE}) \text { it }+\beta 9(\mathrm{ERM} * \mathrm{ACE}) \text { it }+ \\
\beta 10(\mathrm{Lev}) \text { it }+\beta 11(\mathrm{PBV}) \text { it }+\beta 12(\text { Size }) \text { it }+\beta 13(\mathrm{ROA}) \text { it }+ \\
\beta 14(\mathrm{PER}) \text { it }+ \text { cit }\end{array}$}} \\
\hline & & & & \\
\hline & $\begin{array}{l}\text { Results } \\
\text { Expectations }\end{array}$ & Coefficient & p-value & Significance \\
\hline ERM & - & -0.738 & 0.003 & $* * *$ \\
\hline ACE & - & -0.475 & 0.057 & * \\
\hline ERMACE & - & $-0,846$ & 0.048 & ** \\
\hline LEV & + & 0.159 & 0.024 & ** \\
\hline$\overline{\mathrm{PBV}}$ & - & -0.219 & 0.069 & $*$ \\
\hline SIZE & - & $-0,815$ & 0.017 & $* *$ \\
\hline ROA & - & -0.016 & 0.095 & * \\
\hline PER & - & $-1,139$ & 0.036 & ** \\
\hline _Cons & & -0.266 & 0.049 & \\
\hline R Squared & $21,536 \%$ & & & \\
\hline Adj R Squared & $19.017 \%$ & & & \\
\hline Prob> F & 0.001 & & & \\
\hline \multicolumn{5}{|c|}{ *** Significance at level 1\% (one-tailed) } \\
\hline \multicolumn{5}{|c|}{ ** Significance at level 5\% (one-tailed) } \\
\hline \multicolumn{5}{|c|}{ * Significance at level $10 \%$ (one-tailed) } \\
\hline \multicolumn{5}{|c|}{$\begin{array}{l}\text { Information: } \\
\mathrm{EV}=\text { earnings volatility; } \mathrm{ERM}=\text { Enterprise Risk Management, is the effectiveness of ERM implementation } \\
\text { score; } \mathrm{ACE}=\text { Audit Committee Effectiveness, is the effectiveness score of the audit committee;ERMACE = the } \\
\text { interaction between the effectiveness of ERM implementation and the effectiveness of the audit } \\
\text { committee; } \mathrm{LEV}=\text { leverage ratio }, \text { proxied by the ratio of total debt per total asset } ; \mathrm{PBV}=\text { price to book value } \\
\text { ratio } \text { SIZE = firm size proxies with natural logarithm of total assets } ; \mathrm{ROA}=\text { return on asset ratio } ; \text { PER } \\
\text { = price earnings ratio }\end{array}$} \\
\hline
\end{tabular}

Meanwhile, the results of model 3 testing in Table 5 show that the independent variables used are ERM, the moderating variables AQ and ERMAQ, and the control variables are LEV, PBV, SIZE, ROA and PER have the ability of $16.807 \%$ to explain the dependent variable EV, slightly smaller than the percentage in both previous models. In this model 3 emphasis is given to see if the 
audit quality proxied by using Big Four or non-Big Four KAP measures can weaken the negative relationship or moderate the relationship between ERM implementation and earnings volatility. The audit quality variables denoted by ERMAQ show no significant results with a pvalue of 0,780 . The results of this study consistently show that audit quality performed by independent auditors is also not able to moderate the negative relationship between the effectiveness of ERM implementation with earnings volatility. The results of this study are similar to the research conducted by Andarini and Januarti [14] which also proves that audit quality has no effect on ERM implementation in the company. The absence of correlation or influence of audit quality on earnings volatility and the inability of audit quality in moderating the negative relationship between the effectiveness of ERM implementation and earnings volatility level in this research is suspected due to the use of a proxy assessment of audit quality which is very simple. The audit quality assessment in this study only uses the Big Four and Non-Big Four KAP size proxies, which may not be relevant enough to assess the actual audit quality.

Table 5: Table Results of Regression Testing Model 3

\begin{tabular}{|c|c|c|c|c|}
\hline \multicolumn{5}{|c|}{ Regression Result Model 3} \\
\hline \multicolumn{5}{|c|}{$\begin{array}{l}\text { Hypothesis 3: The negative relationship between the effectiveness of ERM implementation } \\
\text { and earningsvolatility can be moderated by audit quality }\end{array}$} \\
\hline \multicolumn{5}{|c|}{$\begin{array}{l}\text { Model 3: } E V \text { it }=\beta 0+\beta 15(\mathrm{ERM}) \text { it }+\beta 16(\mathrm{AQ}) \text { it }+\beta 17(\mathrm{ERM} * \mathrm{AQ}) \text { it }+ \\
\beta 18(\mathrm{Lev}) \text { it }+\beta 19(\mathrm{PBV}) \text { it }+\beta 20(\text { Size }) \text { it }+\beta 21(\mathrm{ROA}) \text { it }+ \\
\beta 22(\mathrm{PER}) \text { it }+\varepsilon \text { it }\end{array}$} \\
\hline Variables & Results Expectations & Coefficient & p-value & Significance \\
\hline ERM & - & -0.595 & 0.006 & $* * *$ \\
\hline $\mathrm{AQ}$ & - & 0.084 & 0.857 & \\
\hline ERMAQ & - & 0.036 & 0.780 & \\
\hline LEV & + & 0.299 & 0.025 & $* *$ \\
\hline PBV & - & -0.295 & 0.062 & $*$ \\
\hline SIZE & - & $-1,043$ & 0.011 & $* *$ \\
\hline ROA & - & $-0,020$ & 0.092 & $*$ \\
\hline PER & - & $-1,046$ & 0.039 & $* *$ \\
\hline _Cons & & -0.766 & 0.419 & \\
\hline R Squared & $19,086 \%$ & & & \\
\hline Adj R Squared & $16,807 \%$ & & & \\
\hline Prob > F & 0.006 & & & \\
\hline \multicolumn{5}{|c|}{ *** Significance at level 1\% (one-tailed) } \\
\hline \multicolumn{5}{|c|}{ ** Significance at level 5\% (one-tailed) } \\
\hline \multicolumn{5}{|c|}{ * Significance at level $10 \%$ (one-tailed) } \\
\hline \multicolumn{5}{|c|}{$\begin{array}{l}\text { Information: } \\
\text { Information: } \\
\text { EV = earnings volatility, is the standard deviation of profit; ERM = Enterprise Risk } \\
\text { Management, is the effectiveness of ERM implementation score; AQ = Audit Quality, is an } \\
\text { audit quality score; ERMAQ = interaction between effectiveness of ERM implementation } \\
\text { with audit quality; LEV = leverage ratio, proxied by the ratio of total debt per total asset; PBV } \\
\text { = price to book value ratio; SIZE = firm size proxies with natural logarithm of total assets; } \\
\text { ROA = return on asset ratio; PER = price earnings ratio }\end{array}$} \\
\hline
\end{tabular}


Table 6: Result of Regression Testing Model 4

\section{Regression Result Model 4}

Hypothesis 4: The negative relationship between the effectiveness of ERM implementation and earnings volatility can be moderated by the effectiveness of the audit committee and the quality audit

\begin{tabular}{|c|c|c|c|c|}
\hline $\begin{array}{l}\text { Model 4: } \mathrm{EV}_{\text {it }} \\
\left(\mathrm{ERM}^{*} \mathrm{AQ}\right)_{\mathrm{it}}+\end{array}$ & $\begin{array}{l}30+\beta 23(\mathrm{ERM})_{\mathrm{it}}+\beta 2 \\
(\mathrm{LeV})_{\mathrm{it}}+\beta 29(\mathrm{PBV})_{\mathrm{it}}+\end{array}$ & $\begin{array}{l}(\mathrm{ACE})_{\mathrm{it}}+\beta \\
30\left(\text { Size }_{\mathrm{it}}+\right.\end{array}$ & $\begin{array}{l}\text { 2) })_{\text {it }}+\beta 26 \\
\mathrm{OA})_{\mathrm{it}}+\beta\end{array}$ & $\begin{array}{l}\left(\mathrm{RM} \mathrm{M}^{*} \mathrm{ACE}\right)_{\mathrm{it}}+\mathrm{B} 27 \\
(\mathrm{PER})_{\mathrm{it}}+\varepsilon_{\mathrm{it}}\end{array}$ \\
\hline Variables & Results Expectations & Coefficient & p-value & Significance \\
\hline ERM & - & $-0,562$ & 0,003 & $* * *$ \\
\hline $\mathrm{ACE}$ & - & $-0,499$ & 0,054 & $*$ \\
\hline $\mathrm{AQ}$ & - & 0.079 & 0,859 & \\
\hline ERMACE & - & $-0,853$ & 0.046 & $* *$ \\
\hline ERMAQ & - & 0.035 & 0.779 & \\
\hline LEV & + & 0,250 & 0,016 & $* *$ \\
\hline PBV & - & $-0,295$ & 0,062 & $*$ \\
\hline SIZE & - & $-0,957$ & 0.012 & $* *$ \\
\hline ROA & - & $-0,035$ & 0,064 & $*$ \\
\hline PER & - & $-1,164$ & 0,038 & $* *$ \\
\hline _Cons & & $-0,271$ & 0.237 & \\
\hline R Squared & $20,082 \%$ & & & \\
\hline Adj R Squared & $17,103 \%$ & & & \\
\hline Prob > F & 0,000 & & & \\
\hline$* * *$ Significanc & tevel 1\% (one-tailed) & & & \\
\hline ** Significance & level 5\% (one-tailed) & & & \\
\hline * Significance $a$ & vel $10 \%$ (one-tailed) & & & \\
\hline $\begin{array}{l}\text { Information: } \\
\text { EV = earnings } \\
\text { implementation } \\
\text { audit committe } \\
\text { between the e } \\
\text { committee; ER } \\
\text { quality; LEV = } \\
\text { book value ratic } \\
\text { on asset ratio; P }\end{array}$ & $\begin{array}{l}\text { atility; ERM = Enterpr } \\
\text { ore; ACE = Audit Comn } \\
\text { AQ = Audit Quality, is } \\
\text { tiveness of ERM im } \\
Q=\text { interaction betwee } \\
\text { erage ratio, proxied by } \\
\text { IZE = firm size proxies } \\
=\text { price earnings ratio }\end{array}$ & $\begin{array}{l}\text { Risk Mana } \\
\text { ttee Effective } \\
\text { audit qualit } \\
\text { ementation } \\
\text { effectiveness } \\
\text { e ratio of tota } \\
\text { ith natural lo }\end{array}$ & $\begin{array}{l}\mathrm{t} \text {, is the } \\
\mathrm{s} \text { the effe } \\
\mathrm{e} \text {; ERM } \\
\mathrm{e} \text { effect } \\
\mathrm{RM} \text { impl } \\
\text { per total } \\
\mathrm{n} \text { of total }\end{array}$ & $\begin{array}{l}\text { ctiveness of ERM } \\
\text { veness score of the } \\
E=\text { the interaction } \\
\text { ness of the audit } \\
\text { entation with audit } \\
\text { set; PBV = price to } \\
\text { sets; ROA = return }\end{array}$ \\
\hline
\end{tabular}

From the result of the 4th hypothesis test in research model 4 in table 6 on the relationship of each independent variable, moderation, and a control variable, simultaneously those variables have the ability to influence earnings volatility variable. Only partially, the effectiveness of the ERM implementation, the effectiveness of the audit committee (ACE and ERMACE), and the control variables LEV, PBV, SIZE, ROA, and PER alone are able to negatively affect the earnings volatility level. Audit quality is not able to weaken the negative relationship between the effectiveness of ERM implementation with earnings volatility. Audit quality does not have a significant effect on the relationship between the effectiveness of ERM implementation with earnings volatility, or in other words, a company with high audit quality may not necessarily apply 
ERM effectively. Audit quality also may not affect the achievement of lower earnings volatility level. From the result, it can be concluded that hypothesis 4 in this research is a negative correlation between the effectiveness of ERM implementation with earnings volatility simultaneously can be moderated with audit committee effectivity,and high audit quality is rejected because the result of the research does not support the hypothesis.

\section{Conclusion}

From the results of the research that has been done, in general,it can be concluded that the effective implementation of ERM will have a negative effect on earnings volatility company, which is in line with prediction provided by the stewardship theory. These results are supported by the regression test performed on models 1 through 4 of this study which resulted in a significant negative coefficient direction of the ERM variable to the EV variable. The negative effect of ERM implementation on earnings volatility can be moderated by the role of the audit committee, butcannot be moderated by the company's external supervision through independent external auditors. Internal oversight provided through the audit committeeis found to strengthen the negative relationship between ERM implementation and earnings volatility, but the external oversight provided by the company's independent auditor is unable to moderate the negative relationship between ERM implementation and earnings volatility, even if the auditor is Big Four. The absence of the role of audit quality on earnings volatility and the inability of audit quality in moderating the negative relationship between the effectiveness of ERM implementation and earnings volatility level in this research might be causedby the use of proxy of audit quality which is very simple. The audit quality in this study is only measured by Big Four and Non-Big Four proxies, which may not be relevant enough to assess the actual audit quality. All control variables used in this study, namely leverage ratio (LEV), price to book value ratio (PBV), firm size (SIZE), return on assets (ROA), and price earnings ratio (PER) have a significant relationship to earnings volatility, with the directionin accordance with research expectation.

Some suggestions that the author may provide for further research include; 1) Subsequent research is expected to use broader proxies to measure audit quality, such as external auditor specialization, independence of external auditors, or other proxies, 2) Further research can use a broader sample for example by conducting research on all companies or performing comparison with other regions and other countries.

\section{References}

[1] B. Djohanputro, Manajemen Risiko Korporat Terintegrasi. Jakarta: PPM Manajemen, 2013.

[2] Edmonds et al., "Do risk management activities impact earnings volatility. Journal of Research in Accounting Regulation 27, 66-72.," 2015.

[3] J. Akbari, F. Samadi, and M. and Jafari, "Investigating the influence of risk management on earnings volatility of the listed companies in Tehran stock exchange," International Journal of Advanced Biotechnology and Research, vol. 7, pp. 784-790, 2016.

[4] C. T. Edmonds, J. E. Edmonds, R. D. Leece, and T. E. Vermeer, "Do risk management activities impact earnings volatility," Journal of Research in Accounting Regulation, vol. 27, pp. 66-72, 2015.

[5] OECD, “G20/OECD principles of Corporate Governance.," 2015.

[6] B. Djohanputro, Manajemen Risiko Korporat Terintegrasi. Jakarta: PPM Manajemen, 2013. 
[7] W. Andriani, Sukartini, and R. FithriMeuthia, "PengaruhKompetensi dan Independensi Dewan KomisarisTerhadapPelaksanaan Good Corporate Governance,” No.2 Desember 2007 ISSN 1858-3687, hal 33-46, vol. 2, 2003.

[8] C. T. Edmonds, J. E. Edmonds, R. D. Leece, and T. E. Vermeer, "Do risk management activities impact earnings volatility," Journal of Research in Accounting Regulation, vol. 27, pp. 66-72, 2015.

[9] F. C and L. G, "Enterprise risk management and firm performance: The Italian case. Journal of The British Accounting Review," 2016.

[10] J. Akbari, F. Samadi, and M. and Jafari, "Investigating the influence of risk management on earnings volatility of the listed companies in Tehran stock exchange," International Journal of Advanced Biotechnology and Research, vol. 7, pp. 784-790, 2016.

[11] C. T. Edmonds, J. E. Edmonds, R. D. Leece, and T. E. Vermeer, "Do risk management activities impact earnings volatility," Journal of Research in Accounting Regulation, vol. 27, pp. 66-72, 2015.

[12] I. Chen and S. Chen, Corporate Governance and Investment Efficiency of Diversified firms: Evidence from Corporate Asset Purchases. 2013.

[13] M. A. an. B. Huselid and B.E., Bridging micro and macro domains: workforce differentiation and strategic human resource management,Journa lof Management,Vol.37No.2,pp.421-428. 2010.

[14] W. Andriani, Sukartini, and R. FithriMeuthia, "Pengaruh Kompetensi dan Independensi Dewan KomisarisTerhadap Pelaksanaan Good Corporate Governance," No.2 Desember 2007 /SSN 1858-3687, hal 33-46, vol. 2, 2003. 
